\title{
ЗЛОЧИНИ ПРОТИ ГРОМАДСЬКОГО ПОРЯДКУ ТА МОРАЛЬНОСТІ В ЗАКОНОДАВСТВІ УКРАЇНИ ТА КРАЇНАХ ЕВРОПЕЙСЬКОГО СОЮЗУ
}

\author{
БАЙДА АНтон Олександрович - кандидат юридичних наук, доцент кафедри \\ кримінального права № 1 Національного юридичного університету імені Ярослава \\ Мудрого \\ РУДИКА Владислава Ярославівна - студентка 3 курсу Національного \\ юридичного університету імені Ярослава Мудрого
}

DOI:10.32782/LAW.2020.1.19

УДК 343

y uуй статті досліджено теоретичні питання переліку та складу злочинів проти громадсъкого порядку та моральності в Украӥні у порівнянні зі законодавством краӥн Европейсъкого Союзу. Оглянуто потребу аналізу іноземного законодавства, дослідження науки кримінального права та кримінального законодавства іноземних країн. Практичність підходу адаптування зарубіжного законодавства до національного полягає в тому, щзоб побачити вплив на розвиток національного законодавства позитивного зарубіжного досвіду насамперед тих країн, начіональні правопорядки яких є найбільш сумісними з правовою системою України. Було проведено аналогію переліку злочинів проти громадсъкого порядку та моральності в украӥнсъкому кримінальному законодавстві та таких країн як Франція, Польша, Німеччина, Аатвія, Голландія тощо.

Ключові слова: кримінальне право, злочини проти громадського порядку та моральності, законодавство Европейсъкого Союоз.

Постановка проблеми

Одним із основоположних елементів ефективної протидії злочинності є правильна кримінально-правова оцінка поведінки особи, що грунтується на встановленні ознак кримінального правопорушення, закріплення відповідної норми та встановлення відповідності цих ознак складу злочину. Належна кваліфікація покликана усувати суперечності та неоднозначні підходи до визначення діянь конкретно передбаченими злочинами. Станом на 2019 рік Україна посідала досить низьку 150 сходинку із 163-х позицій за міжнародним рейтингом найбезпечніших для життя країн під назвою Global Peace Index. Цей фактор вказує на те, що у законодавстві та системі правоохоронних органів існують проблеми, які потребуть поступовго вирішення. Відомості про зареєстровані кримінальні правопорушення узагальнюються у звітності №1 «Сдиний звіт про кримінальні правопорушення», що формується щомісячно 3 наростаючим підсумком з початку звітного періоду на підставі даних, внесених до Сдиного реєстру досудових розслідувань. Відтак протягом січня-вересня 2018 року було зареєстровано, наприклад, 8909 випадків вчинення такого кримінального правопорушення як групове порушення громадського порядку та 3959 випадків здійснення наруги над могилою, іншим місцем поховання або над тілом померлого, 2367 випадків сутенерства. Як бачимо, статистика невтішна, що вказує на важливість вивчення зарубіжного досвіду з цього питання та імплементацію в національне законодавство. [1, с.6]

\section{Аналіз останніх досліджень та публікацій}

Аналіз судової практики у цій сфері, наукових статей, праць провідних юристів та працівників правоохоронних органів вказують на численні проблеми правозастосування та кваліфікації злочинів проти громадського порядку та моральності. Насамперед, це зумовлено недосконалістю правотворчої техніки, 


\section{Кримінальне право, кримінальний процес та криміналістика}

неоднозначності формулювань норм та різного їх тлумачення. Характеристику злочинів проти громадського порядку та моральності досліджували у своїх працях такі вчені, як: M.I. Бажанов, В.В. Дзундза, I.M. Даньшин, В.В. Вітвицька, С.Ф. Денисов, , О.О. Дудоров, П.П. Михайленко, І.Я. Козаченко, І.М. Копотун, , О.М. Костенко, М.Й. Коржанський, А.В. Ландіна, П.С. Матишевський, Л.О. Кузнецова, , В.О. Навроцький, Г.I. Піщенко, , В.I. Осадчий, В.В. Налуцишин, М.I. Панов, А.С. Кучанська, С. П. Репецький, Р.П. Олійничук та інші.

\section{Виділення не вирішених раніше частин загальної проблеми}

Після підписання Угоди про асоціацію між Україною та Європейським Союзом, Україна обрала чіткий і стабільний вектор свого розвитку, а тому на порядку денному стоїть вирішення таких питань як шляхи європейської інтеграції та приведення українського законодавства у відповідність європейському. Стандарти сучасного демократичного суспільства, які $\epsilon$ гаслом існування та розвитку європейських країн, зумовлюють перегляд чинних кодифікованих актів, і Кримінальний кодекс України не є виключенням. Залишається недостатньо дослідженими основні аспекти кримінально караних діянь, які посягають на суспільний порядок та моральні цінності, використовуючи метод компаративістики.

\section{Мета статті}

Значення проведеного дослідження полягає у застосуванні методу компаративістики для аналізу основних характеристик злочинів проти громадського порядку та моральності у кримінальному законодавстві України та країн Европейського Союзу.

\section{Виклад основного матеріалу дослідження}

У Конституції України закріплений примат міжнародно-правових актів над нормативно-правовими актами України. У Кримінальному кодексі дублюється це положення про те, що кримінальне законодавство засноване на загальновизнаних принципах та нормах міжнародного права. В.В. Налуцишин 3 приводу цього питання вказує на наявність потреби аналізу іноземного законодавства, дослідження науки кримінального права та кримінального законодавства іноземних країн. Основною метою залучення іноземного досвіду у кримінально-правову сферу є узгодження політики держави щодо недопущення інтернаціональності злочинності. Як вважає В.В. Налуцишин: «Практичність підходу адаптування зарубіжного законодавства до національного полягає в тому, щоб побачити вплив на розвиток національного законодавства позитивного зарубіжного досвіду насамперед тих країн, національні правопорядки яких є найбільш сумісними з правовою системою України». [2, с. 33]

Компаративістика у юриспруденції (лат. Сотраго - порівнюю) -це метод вивчення правових систем різних держав шляхом зіставлення систем права, однойменних державних і правових інститутів, принципів права і правових норм. Можливості цього методу використовуються також для вирішення кримінально-правової проблематики, серед яких: по-перше, існування гармонізованих, уніфікованих кримінально-правових норм у межах держав, що є членами ООН, міжнародно-правових норм прямої дії, зокрема таких як «Поняття злочину», «види кримінального покарання», «обставини, що пом'якшують та обтяжують покарання» тощо; по-друге, дає змогу врахувати тенденції міжнародного права, особливо тих, що стосуються сфери прав людини. По-третє, декриміналізація у тих випадках де це є доцільним та актуальним, підвищення ролі кримінально-правового заохочення. По-четверте, вирішення проблем колізій у законодавствах. [3, 18-20]

Для початку, варто проаналізувати, яким чином згрупували та як характеризують вітчизняні законодавці злочини проти громадського порядку та моральності. Громадський порядок - це суспільні відносини, що забезпечують нормальні умови у різних сферах життєдіяльності людей. Моральність полягає, насамперед, в закріпленні етико-культурних норм, правил поведінки, які закріпилися за певним суспільством на основі традицій та історико-культурних факторів. [4, с.559-567] Беручи до уваги особливості безпосередніх об'єктів цих злочинів, їх можна поділити на 2 групи:1)злочини проти громадського 
порядку(групове порушення громадського порядку; масові заворушення; заклики до вчинення дій, що загрожують порушенню масовому порядку; хуліганство); 2)злочини проти моральності(наруга над могилою; знищення, руйнування або пошкодження пам'яток - об'єктів культурної спадщини та самовільне проведення пошукових робіт на археологічній пам'ятці; знищення, пошкодження або приховування документів чи унікальних документів Національного архівного фонду; жорстоке поводження з тваринами; ввезення, виготовлення або розповсюдження творів, що пропагують культ насильства і жорстокості; ввезення, виготовленні та збут порнографічних предметів; створення або утримання місць розпусти і звідництво; сутенерство або втягнення особи в заняття проституцією; втягнення неповнолітніх у злочинну діяльність). [5]

Група злочинів проти громадського порядку та моральності бере свій початок з XIX століття. Підходи щодо їх визначення були суперечливими. Деякі країни ототожнювали ïх зі злочинами проти сексуальної свободи та моральності (Угорське кримінальне уложення) та злочинами проти основ національної безпеки (Кримінальний кодекс Франції). Історично злочини проти громадського порядку в джерелах континентальних систем права ототожнювалися зі «life crimes», що має на увазі злочини в повсякденному житті. Кожна окрема людина є відображенням накладених моральних принципів та установок, культури, звичок, виховання, а тому правила поведінки, які прививаються з дитинства сприяють тому, що індивіди, незалежно від віку, статі, раси, національності розуміють та вірять, що погані манери, незадовільна поведінка у публічних місцях може зруйнувати якість життя. Інші ж навпаки вбачають у криміналізації таких діянь посягання на свободу окремих людей. [6, с. 369-370] Наприклад, Кримінальний закон Польщі закріплює аналогічні злочинам проти громадського порядку та моральності в розділі про злочини проти сексуальної волі та моральності й про злочини проти публічного порядку.[7, с. 177] У кримінальному законодавстві Голландії глава сьома та восьма всановлює відповіальність за злочини, що загрожують загальній безпеці людей і власності та зло- чини проти державної влади. Кримінальний кодекс Іспанії закріплює аналогічні норми у розділі двадцять другому: злочини проти громадського порядку. [8, с.256] Провівши аналіз кримінального законодавства деяких країн Європейського Союзу, що належать до різних правових систем, було встановлено такий факт, що тотожні склади злочинів, віднесені Кримінальним кодексом України до злочинів проти громадського порядку та моральності відсутні, а віднесені до різних груп кримінальних правопорушень, що певною мірою залежить від того, що саме держава тлумачить під порядком та моральністю. Так чи інакше, вони мають різні назва або розміщені у різних розділах, що вказує на різні підходи до їх визначення. Наприклад, лише в кримінальному законі Франції встановлена відповідальність за групові порушення громадського порядку, інші країні криміналізують масові заворушення, до яких відносяться і ті, які є груповими порушеннями громадського порядку.

Перелік кримінальних правопорушень, які підпадають під критерій посягання на громадський порядок та моральність у різних країнах свій чітко визначений, але за загальним правилом до них належать: хуліганство, масові заворушення, блокування та створення перешкод для руху транспорту, вандалізм, розпиття алкогольних напоїв, проституція, розповсюдження порнографії, жорстоке поводження 3 тваринами, посягання на основні моральні принципи і цінності у сфері духовного життя, у сфері статевих відносин тощо.

Розглянемо цю групу злочинів на прикладі Республіки Франції, що належить до континентальної системи права. Стаття 431-4 Кримінального Кодексу Франції встановлює караність за діяння, що не знайомі українському кримінальному законодавству, а саме, діяння особи, у якої відсутня зброя, що полягають в умисному продовження участі у зібранні після вимог суб’єкта владних повноважень припинити ці дії. Виділення як родового об'єкту - громадський спокій (Книга 4 - про злочини й провини проти націй, держави й громадського спокою, про посягання на державну владу, посягання на громадський спокій КК Франції) та державні й суспільні основи вказує на схожість 3 вітчизняним законодавством. [6, с. 369-370] Відмінність проявляється в тому, 


\section{Кримінальне право, кримінальний процес та криміналістика}

що в українському законодавстві наголос зроблено на громадському порядку в цілому, а в країнах Европейського Союзу виділяють саме громадський спокій, який є складовою громадського порядку. Зокрема, і посилена відповідальність встановлена за такі протиправні діяння як участь у зборищах, натовпах, що безпосередньо завдають шкоди громадському спокою. 3 цього логічно виходить висновок, що країни Західної Европи (на прикладі Франціі) дуже поважають та охороняють свій особистий та суспільний простір, емоційне та психологічне благополуччя, встановлюючи кримінальні санкції за діяння, які посягають на них.

Дослідження законодавства країн Европи показує, що майже всі містять у власних кримінальних законах відповідальність за дії, мотивовані явною неповагою до суспільства хуліганство. Беззаперечно, назва цього кримінального караного діяння може відрізнятися і залежить від того, яке значення в нього вкладає та чи інша держава. Це може бути «хуліганство», як в Україні та в більшості пострадянських країн, «хуліганські дії», як у Кримінальному кодексі Голландії, «злісне хуліганство» у Естонії тощо. Наприклад, кримінальне законодавство Голландії (статтях 142-143) та Іспанії (статті 557, 558) основними ознаками цього злочину закріплюють публічність та зухвалість. [8, с.257] У свою чергу, Кримінальний кодекс України публічний характер такого діяння не є обов'язковим. [12, с.643] Деякі країни пов'язують вчинення хуліганських дій з актами сексуального характеру. У Кримінальному кодексі Федеративної республіки Німеччина передбачена відповідальність за публічні сексуальні дії, якими умисно чи усвідомлено порушено норми суспільної моралі у вигляді позбавлення волі на термін до одного року або штраф. [9, с.347-350]

Доцільним буде наголосити на тому факті, що не всі кримінальні закони країн Европейського Союзу встановлюють відповідальність за створення та утримання місць розпусти. Неоднозначним залишаються і підходи в питаннях криміналізації проституції. Лише п'ять країн Європи, такі як: Німеччина, Австрія, Аіхтенштейн, Нідерланди та Греція легалізували місця розпусти. Сімнадцять країн декриміналізували проституцію на законодав- чому рівні, але заборонивши при цьому «борделі». У дванадцяти країнах Европейського Союзу проституція навпаки визнається кримінально караним діянням та навіть передбачена кримінальна відповідальність повій. Норвегія, Ісландія встановили кримінальну відповідальність також і клієнтів. В Україні 3 2006 року заняття проституцією декриміналізовано, але й не легалізовано, тобто це питання конкретно не вирішено. Це вказує на те, що ще не вироблений єдиний підхід з цього приводу, а дискусії точаться до сих пір. Кримінальний кодекс Франції чітко регламентує у статті 225(10) відповідальність за створення та утримання місць розпусти. [6, с.371] Ця норма стосується саме володіння, використання, фінансування чи сприяння будь-якими діями закладу в систематичному допуску та пошуку клієнтів для задоволення фізичних потреб сексуального характеру.

Встановлення мінімального віку для притягнення до відповідальності за злочини проти громадського порядку та моральності характеризується також своїми особливостями. Наприклад, суб’єктом групового порушення громадського порядку у більшості країн Свропи є особа, яка досягла 14-річного віку. Франція знизила вік такої особи до 13 років. Дивлячись на національне законодавство, то лише чітко вказаний перелік злочинів передбачає відповідальність у такому ранньому 14-річному віці, а суб'єктом групового порушення громадського порядку може бути тільки 16-річна особа. У свою чергу, країни Свропи зниження мінімального віку притягнення до кримінальної відповідальності пояснюють особливостями розвитку розумових здібностей дитини, яка вже може і повинна повноцінно розуміти значення та наслідки своїх дій та поважати суспільство. [6, с.371]

Для порівняння суворості санкцій за злочини проти громадського порядку візьмемо групове порушення громадського порядку, що є одним з найменш суспільно небезпечних діянь у цій групі злочинів. Найбільш жорсткі покарання встановлені у Молдові та Аатвії. У статті 226 Кримінального кодексу Аатвії встановлено максимальне покарання у вигляді позбавлення волі на строк до 6 років, а стаття 285 Кримінального кодексу Молдови - до 10 років позбавлення волі. В Україні зовсім по- 
іншому: групове порушення громадського порядку карається лише штрафом або арештом на строк до 6 місяців. [10,с.323;1 1, с.246; 4]

\section{Висновки}

Отже, злочини проти громадського порядку та моральності являють собою діяння, які не відповідають загальним ідеям та уявленням соціуму про поведінку та правопорядок та моральним цінностям. Їхня суспільна небезпечність полягає в тому, що такі діяння є особливо деструктивними для суспільства, оскільки вносять розлад до повсякденного, нормального функціонування спільноти. У кримінальному законодавстві України наведений розширений перелік злочинів, які посягають на громадський порядок та моральність, що створює невизначеність та двозначність у застосуванні тих чи інших норм. Залишаються складними питання розмежування хуліганства від дрібного хуліганства, масові заворушення від злочинів проти громадського порядку, що потребує якісної довготривалої судової практики 3 цих питань, щоб дотримуючись принципу правової визначеності, об'єктивно розуміти та відрізняти одне діяння від іншого. Европейське законодавство, з одного боку, визначає аналогічні діяння, що і в Україні, як такі, що порушують громадський порядок та моральність, але, 3 іншого боку, $е$ і суттеві відмінності, які полягають в тому, що чимало злочинів віднесені до інших груп: злочинів проти життя та здоров'я, проти держави та нації тощо, а деякі 3 них навпаки декриміналізовані, наприклад проституція чи утримання місць розпусти. Вивчення основних відмінностей, аналіз рівня злочинності та розкриття злочинів у Европі та Україні дає змогу зрозуміти, які саме позитивні аспекти європейського законодавства варто запозичити.

\section{Аiтература}

1. Інститут економіки та миру//Global Peace Index 2019. Вимір миру у світі, Сідней, червень 2019. URL: http://visionofhumanity. org/reports (Дата звернення: 05.03.2020p.).

2. Налуцишин В. Проблеми відмежування хуліганства від суміжних злочинів. Вісник прокуратури. № 5 (59) травень 2006. С. 46-53.
3. Селіванов В.М. Право і влада суверенної держави: методологічні аспекти: монографія / за ред. Селіванов В. М. : Ін Юре, 2002. c.724

4. Олійничук Р. П. Наукові підходи до дефініції -громадський порядок як соціально-правового явища / Всеукраїнська науковопрактична конференція - Формування правової держави в Україні. Тернопіль : Тернограф, 2008. С. 559-567.

5. Кримінальний кодекс України. Закон від 05.04.2001 № 2341-III.

URL: $\quad$ https://zakon.rada.gov.ua/laws/ show/2341-14 (Дата звернення: 07.03.2020p.)

6. Уголовный кодекс Франции / Под редакцией Канд. Юрид. Наук, доц. А. В. Головко, канд. Юрид. Наук, доц. Н. Е. Крыловой. СПб. : Юридический центр Пресс, 2002. 650 с.

7. Уголовный кодекс Республики Польша / Под редакцией Н. Ф. Кузнецовой. Минск : Тесей, 1998. - 128 с.

8. Уголовный кодекс Испании /Под ред. и с предисл. Докт. Юрид. Наук, профес. Н. Ф. Кузнецовой и докт. Юрид. Наук, профес. Ф. М. Решетникова: ЗЕРЦААО. 1998. 218 с.

9. Уголовный кодекс Федеративной Республики Германии / Ред. и вступ. Статья докт. Юрид. Наук, проф. Д. А. Шестакова. СПб: Юридический центр Пресс, 2003. 524 с.

10. Уголовный кодекс Республики Молдова / Под научной редакцией А. И. Аукашов. СПб. : Юридический центр Пресс, 2003. 408 с.

11. Уголовный кодекс Аатвийской Республики / Под научной редакцией Канд. Юрид. Наук А. И. Аукашова и канд. Юрид. Наук Ә. А. Саркисовой. СПб: Юридический центр Пресс, 2001. 313 с.

12. Кримінальний кодекс України: науково-практичний коментар/ Відп. ред. С. $\mathcal{\Lambda}$. Стрельцов. Х.: ТОВ Одісей, 2008. 800 с.

\section{References:}

1. Institute for Economics \& Peace. Global Peace Index 2019: Measuring Peace in a Complex World, Sydney, June 2019. Available at: http://visionofhumanity.org/reports (accessed 05.03.2020).

2. Nalutsyshyn V. (2006) Problemy vidmezhuvannia khulihanstva vid sumizhnykh zlochyniv [Problems with distinction hooliganism and similar crimes]. Proceedings at the Visnyk prokuratury. № 5 (59). pp. 46-53. (In Ukrainian) 


\section{Кримінальне право, кримінальний процес та криміналістика}

3. Selivanov V.M. (2002) Pravo i vlada suverennoi derzhavy: monohrafiia [Law and authority of the independent state]K: In Yure. 724 p. (In Ukrainian)

4. Oliinychuk R. P. (2008) Naukovi pidkhody do definitsii - hromadskyi poriadok yak sotsialno-pravovoho yavyshcha [Scientific approaches to the definition of public order as social phenomenon]. Proceedings at the Vseukrainska naukovopraktychna konferentsiia - Formuvannia pravovoi derzhavy $\mathrm{v}$ Ukraini. Ternopil, 11 kvitnia 2008 r.: Ternohraf, 2008. pp. 559-567. (In Ukrainian)

5. Kryminalnyi kodeks Ukrainy [Criminal code of Ukraine]. Zakon vid 05.04.2001 № 2341-III. URL: https://zakon.rada.gov.ua/laws/ show/2341-14 (accessed : 07.03.2020r.)

6. L. V. Golovko, N. E. Krylovo (2002) Ugolovnyy kodeks Frantsii [Criminal code of France] SPb. : YUridicheskiy tsentr Press. 650 p. (In Russian)

7. N. F. Kuznetsovoy (1998) Ugolovnyy kodeks Respubliki Pol'sha [Criminal code of Poland]. Minsk : Tesey. - 128 p. (In Russian)

8. N. F. Kuznetsovoy, F. M. Reshetnikov (1998) Ugolovnyy kodeks Ispanii [Criminal code of Spain]. : ZERTSALO. 218 p. (In Russian)

9. O. A. Shestakov (2003) Ugolovnyy kodeks Federativnoy Respubliki Germanii [Criminal code of Germany] D: SPb. YUridicheskiy tsentr Press. 524 p. (In Russian)

10. A. I. Lukashov (2003) Ugolovnyy kodeks Respubliki Moldova [Criminal code of Moldova] SPb. : YUri-dicheskiy tsentr Press. 408 p. (In Russian)

11. A. I. Lukashova, E. A. Sarkisova (2001) Ugolovnyy kodeks Latviyskoy Respubliki [Criminal code of Latvia]. SPb. : Yuridicheskiy tsentr Press. 313 p. (In Russian)

12. Ye. L. Streltsov (2008) Kryminalnyi kodeks Ukrainy: naukovo-praktychnyi komentar [Scientific and practical commentary of criminal code of Ukraine]. Kh: TOV Odisei. 800 p. (In Ukrainian)
Bayda Anton, Rudyka Vladyslava

Yaroslav Mudryi National Law University

CRIMES AGAINST PUBLIC ORDER AND MORALITY IN UKRAINIAN AND EUROPEAN LEGISLATIONS

In this article the analysis of crimes against a public peace and morality in Ukrainian and European legislation is conducted. Public order crimes are actions that do not conform to society's general ideas of normal social behavior and moral values. Their social danger consists in destructive consequences for public order because they cause disorder in ordinary people's lives and violate the functioning of the community. In this article is enlightened such a practical tool as a method of comparison that gives an opportunity to figure out problems in national legislation, try to unify terms and absorb positive experience of European countries (France, Latvia, Germany, Poland, Moldova, Netherlands etc). Ukrainian and European legislations have not only many similar aspects but also a huge amount of distinctions. These countries are taken as a model because of lower level of criminal than in Ukraine and high observance, protection and respect of human rights.

Practical value of comparative approach and approach of adaptation consists in borrowing some conceptual ideas and implementation in our national legislation. The opportunities of this method are used for dealing with such a criminal law issues as:1) firstly, harmonization and unification of laws in the countries that are members of UN, directly applicable international laws such as «the notion of crime», «criminal penalties» etc.; 2) secondly, It gives an opportunity to take into account tendencies of international law, especially concerning with human rights. One of the fundamental elements of effective dealing with the crimes is right and accurate criminal estimation and qualification of human`s actions. Such a qualification is based on establishment of all signs of criminal offence and consolidation a specific law. Appropriate qualification aims to eliminate contradictions and ambiguous approaches to definition of deeds as crimes.

So, analisys of main distinctions in legislations, analisys of crime rate statistics of solved crimes in Europe and in Ukraine leads to understanding of what provisions we need to borrow.

Key words: criminal law, crimes against a public peace and morality, European legislation. 